политических институтов основным источником и инициатором преобразований является государственная власть» [7, с. 112] .

Здесь можно согласиться с мнением известного узбекского ученого, академика М. Шарифходжаева, который утверждал, что «...поскольку у нас видимая и решающая роль на этапе обретения независимости принадлежала правительству, то создалось впечатление, что государство строит гражданское общество. На самом деле так и было. Хотя, многие мысли, созвучные идеям гражданского общества, вырабатывались нашими великими предками на протяжении столетий. Но, говоря об этом, надо специально обратить внимание на то, что взгляды многих из них классифицируются в качестве примеров так называемого восточного аристотелизма» [8, c. 138].

Поэтому вполне очевидно, что гражданскому обществу оставалось лишь принять ту модель, которую на первых порах предоставило ему государство. Других моделей просто не было в исторической памяти нашей государственности, начиная с известного труда «Уложения Темура». А поэтому общество вполне спокойно восприняло то, что был принят закон о государственном социальном заказе, положившем начало структурированию гражданского общества по тем направлениям, в которых было заинтересовано государство и это вполне объяснимо.

\section{Список литературы}

1. Мирзиёев Ш. М. Уважение к героизму и памяти предков: выступление Президента Республики Узбекистан на церемонии открытия парка Победы // Правда Востока. 2020. 10 мая.

2. Усманов К. История Узбекистана (19171991 годы). Ташкент, 2011. 224 с.

3. Флин М. В стране слепых. Москва: Смоленск, 1995. 142 с.

4. Сатпаев Д. Деформация вертикали. От анонимных империй до антилобби // Черная папка коммуникационного и политического апгрейда в Казахстане в условиях транзита власти. Алматы, 2019. C. 11-12.

5. Наим М.. Конец власти. От залов заседаний до полей сражений, от церкви до государства, почему управлять сегодня нужно иначе. Москва, 2016. 512 c.

6. Киященко Н. И. Эстетика - философская наука. Москва, 2005. 588 с.

7. Ирисметов Б. М. Общее и особенное в формировании политических систем в странах Центральной Азии. Ташкент, 2011. 135 с.

8. Шарифходжаев М. Формирование открытого гражданского общества в Узбекистане. Ташкент, 2002. 272 с.

\title{
КУЛЬТУРНАЯ ИДЕНТИЧНОСТЬ КАК ВАЖНЫЙ ЦЕННОСТНО-СМЫСЛОВОЙ КОМПОНЕНТ САМОСОЗНАНИЯ НАРОДА В УСЛОВИЯХ ГЛОБАЛИЗАЦИИ
}

Аннотация. В данной статье рассматривается культурная идентичность как важный ценностносмысловой компонент любого народа. Особый акцент в статье делается на теоретическом анализе культурной идентичности с различных методологических точек зрения, анализируются ведущие идеи исследователей в области психологии, социологии, философии и этнографии. Также в статье уделяется внимание процессу глобализации, который способствует размыванию культурных идентичностей народов России, утрате исторических корней, игнорированию культуры и языка.

Ключевые слова: культурная идентичность, культурная идентификаџия, глобализаџия, традиџионная культура, «маркер идентичности», информатизащия, традиции, этнос.

В настоящее время в нашей стране происходит активное разрушение этнокультурных границ, связанное с процессом глобализации мира. Вследствие чего со стороны общества к основам народной традиционной культуры проявляется повы- шенный интерес. Во главу угла ставятся вопросы изучения актуальных проблем культурной идентичности нации, этноса и народностей. Вместе с тем, в современном обществе, достигшем высокой стадии технологического и информационного 
развития, происходит вынужденная трансформация традиционных ценностных ориентиров, нацеленных на культурную идентификацию. Происходящие глобализационные процессы призывают современную науку и общественность более глубоко и всесторонне изучать культурную идентичность как важный ценностно-смысловой компонент культуры любого народа.

На сегодняшний день намечается тенденция к региональным исследованиям национальных, этнокультурных и гражданских аспектов культурной идентичности. Вместе с тем, цивилизационный подход в имеющихся исследованиях вопросов культурной идентичности современной России является приоритетным. Изучению концепций культурной идентичности посвящены труды Н. И. Алексеевой, Ю. В. Арутуняна, О. Н. Астафьевой, 3. Баумана, М. М. Бахтина, А. В. Бурова, А. Вежбицкой, Ю. Г. Волкова, Л. Д. Гудкова, Е. Б. Деминцевой, Л. М. Дробижевой, 3. А. Жаде, М. В. Заковоротной, Л. Г. Ионина, А. В. Костиной, П. И. Кушнера, В. С. Малахова, И. В. Малыгиной, В. М. Межуева, Г. Я. Миненкова, И. В. Мазуренко, В. Пиллиповича, В. И. Пузько, В. А. Ремизова, А. П. Садохина, П. А. Сорокина, В. А. Тишкова, В. А. Шнирельмана, Э. Эриксона и других.

В теоретическом ключе культурная идентичность рассматривается с разных методологических точек зрения и активно связана с психологией, социологией, философией и этнографией. Впервые в научный оборот понятие «идентичность» ввел 3. Фрейд как маркер сохранения своей связи с этнической культурой [1]. Понятие «идентичность» означает тождественность, одинаковость и связано с процессом идентификации (сопоставления одного субъекта с другим, проявления общих или специфических черт). Идентичность рассматривается учеными как реальность, обобщающая процесс идентификации. Отсюда следует, что культурная идентификация представляет собой связь индивидуума с конкретной культурой или культурным обществом. Культурная идентификация, являясь испытываемыми чувствами индивида внутри определенной культуры, воспитывает ценностное отношение индивида к самому себе, другим индивидам, социуму и обществу в целом.

По мнению Э. Эриксона, в современном обществе происходят кризисы идентичности, которые связаны с социально-глобализационными трансформациями взаимоотношений институтов и социальных групп. Данные процессы оказывают значительное влияние на характер и сущность идентификации, они становятся основой для развития культурной идентичности [2].

В философской науке [3; 4; 5; 6] проблемы сохранения культурной идентичности описывают- ся как «конфликт цивилизаций». Известные философы П. Бьюкенен, С. Хантингтон и В. А. Рюмин называют глобализацию фактором, который оказывает значительное влияние на культурную идентичность. Кризис идентичности вызывает ректуализацию, которая является возрождением разрушенной целостности, что непосредственным образом определяет актуальность сегодняшней проблемы сохранения культурных и национальных идентичностей.

В. Хёсле рассматривает сущность и причины кризиса идентичности в глобализационном процессе. Возможные причины кризиса идентичности он видит в «отрицании символов; распаде коллективной памяти, представляемой традициями; утрате веры в будущее; дисгармонии между описательными и нормативными образами себя; прерывности в истории» [7, с. 113]. По мнению исследователя, выход из кризиса идентичности необходимо искать в ее восстановлении, то есть в формировании новой позитивной идентичности на базе миновавшей культурной идентичности.

Идентификацию социологи рассматривают как процесс одновременно объективный и субъективный. Специфика социологического исследования культурной идентичности основывается на анализе сквозь призму глобализации как поля для формирования культурных процессов. По мнению социологов П. Бергера и Т. Лукмана, сведения о своей идентичности заимствуются и постигаются человеком из окружающего социума. Затем в ходе взросления человека его культурная идентификация обретает более осмысленную направленность [8]. Мнения исследователей наталкивают на мысль о том, что процесс возрождения культурной идентичности основывается на целенаправленном и осмысленном возврате к культуре своих предков.

В то же время о значительном влиянии глобализационных процессов на социальное развитие указывает социологи Э. Гидденс и У. Бек, которые вносят свои коррективы в изучение культурной идентификации. По их мнению, процесс отождествления себя с другой культурой в ситуации взаимопроникновения и разнообразия культур приобретает рефлексивную направленность. Глобализация растворяет прежние социальные структуры, происходит процесс наложения и смешения культур, вследствие чего общество становится неконтролируемым и неустойчивым. Глобальное опасение вызывает масштабное распространение современных технологий и их неудержимое развитие. Поэтому жизнь жителей планеты подвергается серьезным рискам, которые связаны с угрозой уничтожения всего человечества или его частей $[9 ; 10 ; 11 ; 12]$. 
Мнения многих социологов схожи в том, что процессы глобализации разрушают обычаи, обрядность и образ жизни человека, а также образ и стиль мышления, ценности и установки поведения. В этом случае культурная идентификация получает статус альтернативной непредсказуемой устремленности. Переменчивость идентификации, по мнению Е. Н. Даниловой и В. А. Ядова, стала как бы правилом современного мира, она предвещает возникновение новых кризисов идентичности, которые будут являться утратой умения приспособиться к происходящим переменам жизни вследствие «культурной травмы» [13, с. 9].

В исследованиях Д. Е. Иванова культурная идентичность приобретает нелинейное и многомерное направление, связанное с мультикультурностью культурного пространства в атмосфере глобализации [14]. Различные исследования социологов направлены на изучение национальных, религиозных, языковых, этнических и политических аспектов идентичности в обязательной взаимосвязи с социальными процессами. Так, к примеру, с точки зрения Ф. Барта, границы этносов устанавливаются самими этносами через выбор главных «маркеров идентичности». Выбор конкретного «маркера идентичности» во многом зависит от социальной, экономической, исторической и политической обстановки в обществе. Как считает социолог, на жизнь социума и поведение его членов влияют этнические границы, основанные на «культурном знании», при этом представления социума и формы его организации являются не постоянными и в любой момент они могут поменяться [15].

Среди современных теоретических разработок проблем культурной идентичности наиболее интересной является концепция В.С. Жидкова. Основами культурной идентичности он называет ее маркеры, к которым относит: землю предков (территорию); историю, прочитанную сквозь общественные идеалы и ценности; язык и культуру; национальный характер как доминирующую психологическую черту [16, с. 148]. Исследователь М. В. Заковоротная считает, что «идентичность это результат сохранения себя, а идентификация механизм, процесс постоянного выбора, принятия норм, установок и традиций» $[17$, с. 125$]$.

В современных условиях развития общества в плане идентичности возникает некое состояние неопределенности. Причинами данного состояния является утрата стабильности, распад представления о себе, дезориентированность, недейственность всеобщих ценностей и норм. Вследствие чего, рушится структура стержневых принципов и та платформа, на основе которой создавались и функционировали общества. Глобализация вносит свои определенные коррективы, отчетливо трансформируя ценностные и мировоззренческие ориентиры человека и конкретного народа. Эта ситуация приводит к культурным и идеологическим конфликтам в сфере идентичности. Представители современной науки психологии размышляют о том, что в процессе развала ценностного порядка, объединяющего общество в единое целое, повышается значимость национальной идентичности как результат безусловного ответа на неопределенность состояния.

Степень интеграции и конкурентоспособности общества в мировом экономическом пространстве находится в сильной зависимости от культурной идентичности в условиях глобализации. Данная интеграция в силах разрушить культурную идентичность, растворить ее в процессе повышения значимости экономических ценностей. Данный процесс, по мнению В. И. Пузько, определяется тем, что «рыночные взаимоотношения вытесняют неконкурентные слои граждан на границу выживаемости и одичания, не позволяют строить культурное бытие и сохранять уважение к своей личности» [18, с. 104].

На существенное изменение состояния и процессы идентификации стран и народов влияет тотальная информатизация современного общества. Со временем сформировалась единая мировая информационная зона, создавшая глобальную сетевую сферу. Данная сфера сделала возможным открытый доступ к познанию и преумножению материальных и духовных благ, а также интеллектуальных ресурсов для устойчивого развития и достижения благополучия людей. Информационная гласность породила угрозу культурной стандартизации, унифицирования, ориентации населения всего мира на ценности западного общества. В этом случае общество теряет свои уникальные и исторические традиции. Другими словами, в сложившейся ситуации некоторые немногочисленные народности могут потерять свою культурную идентичность. На сегодняшний день, по мнению В. Г. Целищевой, «подрастающее поколение данных немногочисленных народностей почти не умеют разговаривать на родном языке, не знают свою культуру ... имеются программы в поддержку и для сохранения национальной культуры, однако в основном они мало чем могут помочь» $[19$, с. 122]. Описанные В. Г. Целищевой актуальные проблемы свойственны большинству регионов России. Как считает К. Гирц, в современной культуре отсутствуют или являются очень слабыми «устойчивые культурные формы, воспроизводящие общественную систему, которые бы установили надежную связь элементов культуры во времени и пространстве. При наличии огромно- 
го культурного потенциала, накопленного предыдущими поколениями, происходит культурное оскудение народов» [12, с. 503]. В. А. Шупер добавляет, что «современная глобализация привела к деструктивным процессам в сфере культуры: кризису культурных, национальных, этнических идентичностей, к гомогенизации, вестернизации и американизации» [20, с. 4]. Таким образом, процессы глобализации активно способствуют размыванию культурных идентичностей народов России, к утрате исторических корней, игнорированию культуры и языка.

Культурная идентичность, являясь ядром традиционной культуры, а также многогранным и полифункциональным явлением, путем ценностного влияния на культурную память, этническую самобытность, преемственность и межпоколенческую трансляцию традиций, встраивается в современную массовую культуру России. Мощным испытанием для культурной идентичности этносов выступают глобализационные процессы как механизм расширения пространства функционирования и взаимодействия национальных культур. Современные информационные технологии сохраняют и развивают культурную идентичность путем реализации регионального брендирования, внедрения различного информационного контента, а также применения разнообразных методов перевода в цифровую форму наследия в области науки, культуры и образования. Благодаря различным порталам Интернета возникает уникальная возможность исчерпывающе отобразить специфику культурной картины конкретного этноса, содействовать развитию межпоколенческих отношений его представителей, а также расширить комплекс средств для укрепления культурной идентичности данного этноса.

\section{Список литературы}

1. Массовая психология и анализ человеческого «Я» // «Я» и «Оно» / 3. Фрейд. Кн. 1. Тбилиси, 1991. С. 71-138.

2. Эриксон Э. Идентичность: юность и кризис. Москва, 1996. 340 с.

3. Бьюкенен П. Дж. Смерть Запада. Москва, 2003. $444 \mathrm{c}$.

4. Рюмин B. A. Глобализация и цивилизационные перспективы человечества // Глобализация в социально-философском измерении. СанктПетербург, 2003. С. 63-65.

5. Хантингтон С. Кто мы? Вызовы американской национальной идентичности. Москва, 2004. $635 \mathrm{c}$.

6. Хантингтон С. Столкновение цивилизаций. Москва, 2003. 605 с.

7. Хёсле В. Кризис индивидуальной и коллективной идентичности // Вопросы философии. 1994. № 10. С. 112-113.

8. Бергер П. Социальное конструирование реальности. Москва, 1995. 322 с.

9. Бек У. Общество риска. На пути к другому модерну. Москва, 2000. 381 с.

10. Бек У. Пятидесятилетняя незнакомка // Internationale Politik. 2008. № 4. С. 14-25.

11. Гидденс Э. Ускользающий мир. Как глобализация меняет нашу жизнь. Москва, 2004. $120 \mathrm{c}$.

12. Гири К. Интерпретация культур. Москва, 2004. $560 \mathrm{c}$.

13. Данилова E. Контекстуально-лабильная идентичность - норма современных динамичных обществ // Социологические исследования. 2004. № 10. C. 1-10.

14. Иванов Д. Е. Эволюция концепции глобализации // Телескоп. 2002. № 4. С. 3-14.

15. Барт $\Phi$. Этнические группы и социальные границы. Москва, 2006. 198 с.

16. Жидков В. С. Культурная идентичность в глобальном мире // Первый Российский культурологический конгресс. Программа. Тезисы докладов. Санкт-Петербург, 2006. С. 148-149.

17. Заковоротная М. В. Идентичность человека: социально-философские аспекты. Ростов-наДону, 1999. 198 с.

18. Пузько В. И. Кризис идентичности личности в условиях глобализации // Философия и общество. 2007. № 4. С. 98-113.

19. Целищева В. Г. Особенности этнической идентичности молодежи малочисленных народов Дальневосточного региона // Социологические исследования. 2007. № 1. С. 122-127.

20. Шупер B. A. Россия в глобализационном мире: альтернативы развития // Вопросы философии. 2008 . № 12. 